\title{
THE MODELING OF OPTIMAL LEVEL OF ENTRANCE FEE FOR CZECH PUBLIC UNIVERSITIES
}

\author{
[Modelování optimální výše zápisného na české veřejné vysoké školy]
}

\author{
Jiří Mazurek $^{1}$ \\ ${ }^{1}$ Slezská univerzita, Obchodně podnikatelská fakulta, Univerzitní nám. 1934/3, 73340 Karviná \\ Email:mazurek@opf.slu.cz.
}

\begin{abstract}
Public universities in the Czech Republic suffer from insufficient funding for many years. One possibility for an increased funding of Czech public universities is an introduction of a low administrative fee called enrollment fee for each semester of a study. The aim of this article is to show how to find the optimal level of the enrollment fee for a given university so the total revenue of a university for enrolling students is maximal. This is done via mathematical model encompassing parameters such as maximal enrollment fee, sensitivity of enrolling students to the level of the enrollment fee, the number of enrolling students, etc. By improperly adjusted enrollment fee a university can lose millions or tens of millions crowns per year. Thus, the determination of the optimal level of the enrollment fee has high practical value, as it enables a university to maximize its combined revenue from the enrollment fee and the number of enrolling students.
\end{abstract}

Keywords: Czech Republic, enrollment fee, mathematical modeling, optimization, total revenue, university.

JEL: C61, I22

Doručeno redakci: 14.8.2015; Recenzováno: 6.9.2015; 21.10.2015; Schváleno k publikování: 15.12.2015

\section{Úvod}

Jedním ze způsobů, jak zlepšit finanční situaci (veřejných) vysokých škol, je spoluúčast studentů. Protože zavedení školného odporuje současné legislativě, přesunula se v posledních letech debata k problematice zápisného, které by mělo fungovat jako nízký administrativní poplatek za každý zapsaný semestr (zápisné se liší od školného tím, že školné by mělo odrážet reálné náklady na studium daného oboru, zatímco zápisné je pouze paušálním administrativním poplatkem za jeden semestr studia). Výše zápisného by byla v kompetenci jednotlivých škol, předpokládá se, že by mohla dosahovat 2500-3000 Kč za semestr ${ }^{1}$.

Nečasova vláda původně hodlala zavést zápisné již v akademickém roce 2012/20132 . Avšak po pádu Nečasovy vlády a po předčasných volbách do Poslanecké sněmovny v říjnu 2013 se vlády ujala středolevá koalice v čele s premiérem Bohuslavem Sobotkou, která ve svém programovém prohlášení jakoukoli formu zápisného či školného odmítla. Je však možné předpokládat, že se diskuse o zavedení zápisného dříve či později opět obnoví, nebot' jde o jednu z mála možností, jak navýšit př́ijmy veřejných vysokých škol, které v současnosti procházejí nucenou restrukturalizací a zeštíhlováním (viz např. VŠB v Ostravě, Slezská univerzita v Opavě, apod.) z důvodu prudkého poklesu př́ijmů ze strany státu (vlivem poklesu zájemců o studium, který je zapříčiněn negativním demografickým vývojem).

K otázce zavedení či nezavedení zápisného však nepanuje ani $\mathrm{v}$ akademickém prostředí jednotný názor. Konference rektorů z dubna 2012 nezaujala k zápisnému žádný postoj, zato

\footnotetext{
${ }^{1}$ Ministr Fiala chce v lednu předložit novelu o zápisném na vysoké školy. VZ24 [online]. [cit. 2012-12-11]. Dostupné z: www.vz24.cz/clanky/fiala-chce-v-lednu-predlozit-novelu-o-zapisnem-na-vysoke-skoly/

2 Tiskový brífink po koaličním jednání [online]. [cit. 2012-12-11]. Dostupné z: www.vlada.cz/scripts/ detail.php?id=99363\&tmplid=50
} 
varovala vládu, že další pokles veřejného financování vysokých škol v příštích dvou letech bude pro vysoké školy likvidační a povede ke snížení konkurenceschopnosti České republiky ${ }^{3}$. Dle názoru rektorů ani zápisné ve výši 3000 Kč nepokryje schodek ve financování vysokých škol. Studentské komory vysokých škol pak jakoukoli podobu zápisného vesměs odmítají a argumentují tím, že podobné poplatky za vysokoškolské studium ve Velké Británii se krátce po jejich zavedení několikanásobně zvýšily. V České republice by byla výše zápisného pravděpodobně omezena shora zákonem, a prrípadné zvýšení maximálního zápisného by muselo nejprve projít parlamentem (což je přinejmenším zdlouhavé).

Hypotetické zavedení zápisného provází i řada nevyjasněných otázek, týkajících se především toho, zda mají zápisné platit všichni (i již studující) studenti, nebo jen studenti nastupující na vysokou školu v novém akademickém roce, nebo zda bude zápisné platit i pro zahraniční (tedy především slovenské) studenty či nikoli. Například v Polsku platí zahraniční studenti jak školné ve výši 200 euro, tak zápisné ve stejné výši ${ }^{4}$, zatímco na Slovensku podobné poplatky neexistují. Některé politické strany navíc již delší dobu avizují, že pokud bude zápisné zavedeno a ony uspějí ve volbách, zápisné zase zruší.

Poměrně opomíjeným aspektem zápisného je, že jeho zavedení nemusí nutně znamenat vyšší finanční prŕínos pro danou vysokou školu, nebot' dojde k přerozdělení zájemců o studium od škol s vysokým zápisným ke školám s nízkým (nulovým) zápisným. Některé studenty (především ze sociálně slabších vrstev) může vyšší zápisné od studia na vysoké škole odradit, a bud' půjdou studovat na jinou vysokou školu s nižším zápisným, nebo raději nastoupí do zaměstnání. Proto se může stát, že vysoká škola po zavedení zápisného získá za studenty nastupující do prvního ročníku méně než bez zápisného, nebot' se sníží jejich počet. Problematice zavedení školného či zápisného se v českém prostředí věnují např́íklad publikace Cahlík et al. (2008) nebo Kubišová a Lánský (2012), v USA pak např́íklad Bosshardt et al. (2009, 2010) nebo Corey (2007).

Cílem článku je proto optimalizovat výši zápisného na českých veřejných vysokých školách tak, aby vysoké školy získaly maximální př́ijem jak ze zápisného, tak z počtu studentů. $\mathrm{K}$ optimalizaci zápisného byl nově vytvořen jednoduchý matematický model, který odráží podmínky českého vysokého školství a zahrnuje parametry jako je maximální výše zápisného, citlivost uchazečů na výši zápisného, počet uchazečů hlásících se na danou vysokou školu, apod. Metoda modelování je v ekonomii poměrně běžná, viz například Cahlík et al. (2008), Craven a Islam (2005), Havelka et al. (1994) nebo Plevný a Žižka (2010). Stanovení optimální výše zápisného má značný praktický význam, nebot' umožní dané vysoké škole maximalizovat svůj př́ijem ze zápisného a za počet přijímaných studentů.

\section{Př́ijem vysoké školy}

\subsection{Přríjem vysoké školy bez zápisného}

Financování veřejných vysokých škol v České republice upravuje § 18 zákona č. 111/1998 Sb. Veřejné vysoké školy mohou být financovány z těchto zdrojů:

- př́spěvky ze státního rozpočtu na vzdělávací a vědeckou, výzkumnou, vývojovou, uměleckou nebo další tvůrčí činnost,

- dotacemi ze státního rozpočtu,

\footnotetext{
${ }^{3}$ Další pokles financování vysokých škol bude likvidační. České noviny [online]. [cit. 2012-12-11]. Dostupné z: www.ceskenoviny.cz/domov/zpravy/rektori-dalsi-pokles-financovani-vysokych-skol-bude-likvidacni/781375

${ }^{4}$ Degrees and Diplomas, Poland: Studies in foreign languages. Ministry of Science and Education [online]. 2007. [cit. 2012-12-11]. Dostupné z: www.nauka.gov.pl /fileadmin/user_upload/_files /Degrees_and_Diplomas.pdf
} 
- poplatky spojenými se studiem,

- výnosy z majetku,

- jinými př́ijmy ze státního rozpočtu, ze státních fondů, z Národního fondu a z rozpočtů obcí a krajů,

- výnosy z doplňkové činnosti,

- př́jjmy z darů a dědictví.

Většinu př́ijmů veřejných vysokých škol tvoří prŕíspěvek ze státního rozpočtu za počet studentů, kde jeden student je dotován určitou částkou (normativem), která v současnosti činí přibližně $28000 \mathrm{Kč}$. Př́ijmy z ostatních výše jmenovaných zdrojů jsou u většiny vysokých škol nepř́liš významné s výjimkou nejlepších univerzit, které navíc získávají značné částky na výzkum z domácích a zahraničních grantových agentur. Tyto př́ijmy však nijak nesouvisejí s př́ípadným zápisným (nejsou jím ovlivněny), a proto dále nebudou uvažovány.

Necht' $n$ je počet přijatých uchazečů a $k$ částka, kterou inkasuje vysoká škola za jednoho přijatého studenta za 1 rok. Bez zápisného je celkový př́jem $T R$ vysoké školy za všechny přijaté studenty za 1 rok roven následující částce:

$$
T R=n \cdot k
$$

Jakmile vysoká škola zavede zápisné, vztah (1) pro celkový př́ijem musí být nahrazen komplexnějším vztahem.

\subsection{Př́ijem vysoké školy se zápisným}

Př́ijem vysoké školy v prrípadě zápisného se bude odvíjet od toho, zda uchazeči o vysokou školu (ne)budou výši zápisného odrazeni. Předpokládejme, že s rostoucím zápisným klesá zájem studentů o studium na vysoké škole lineárně (obecné nelineární závislosti budou prozkoumány v Kapitole 4). Jestliže bez zápisného se na určitou vysokou školu hlásí $N$ uchazečů, po zavedení zápisného bude tento počet nižší.

Úbytek zájemců o studium (počet od studia odrazených studentů) bude označován jako $N \cdot \delta$, kde $\delta$ je „funkce citlivosti“ uchazečů na výši zápisného a v nejjednodušším případě může být definována následovně:

$$
\delta=\gamma \frac{\varepsilon}{\varepsilon_{\max }}
$$

Ve vztahu (2) se, jak již bylo zmíněno, předpokládá lineární závislost $\delta$ na $\varepsilon$. Funkce $\delta=\delta(\varepsilon)$ splňuje následující „okrajové" podmínky:

$$
\begin{aligned}
& \delta(0)=0 \\
& \delta\left(\varepsilon_{\max }\right)=\gamma
\end{aligned}
$$

Podmínka (3a) znamená, že nulové zápisné odradí od studia nulový počet studentů. Podmínka (3b) vyjadřuje, že pro maximální výši zápisného $\varepsilon=\varepsilon_{\max }$ bude od studia odrazeno $N \cdot \gamma$ uchazečů. Např́klad $\gamma=0,4$ znamená, že při maximálním zápisném je od studia odrazeno $40 \%$ uchazečů, $60 \%$ uchazečů se bude dál hlásit na vysokou školu (jedná se o uchazeče, které ani nejvyšší možné zápisné od studia neodradí).

Koeficient $\gamma$ tedy charakterizuje citlivost uchazečů na výši zápisného, a čím vyšší je jeho hodnota, tím větší je úbytek uchazečů o studium. V praxi lze koeficient $\gamma$ zjistit např́íklad dotazníkem u studentů maturitních ročníků nebo ze skutečného (pozorovaného) poklesu zájemců o studium poté, co zápisné vstoupí v platnost. 
Nyní uvažujme, že vysoká škola zavede maximální možné zápisné $\varepsilon=\varepsilon_{\max }$. Počet uchazečů o studium po zavedení maximálního zápisného bude:

$$
\left(1-\delta_{\max }\right) \cdot N
$$

Pak mohou nastat tyto případy (scénáře) podle velikosti $\left(1-\delta_{\max }\right) \cdot N$ a $n$ :

A. $\left(1-\delta_{\max }\right) \cdot N \geq n$ : počet studentů, kteři mají zájem o studium po zavedení maximálního zápisného, je větší nebo roven počtu studentů, které hodlá vysoká škola přijmout. V tomto prŕípadě vysoká škola inkasuje:

$$
T R=n \cdot\left(k+\varepsilon_{\max }\right)
$$

B. $\left(1-\delta_{\max }\right) \cdot N<n$ : počet studentů, kteří mají zájem o studium po zavedení maximálního zápisného, je menší než počet studentů, které hodlá vysoká škola přijmout. V tomto př́padě by vysoká škola inkasovala:

$$
T R=\left(1-\delta_{\max }\right) N \cdot(k+\varepsilon)
$$

Tato částka by však v mnoha př́ipadech nebyla maximálním možným př́ijmem vysoké školy, nebot' počet uchazečù by se mohl snížit natolik, že zavedení maximálního školného by vedlo k poklesu př́ijmu oproti situaci bez zápisného. V tomto případě tedy vysoká škola musí uvažovat o obecně nižším zápisném $\varepsilon$ tak, aby byl následující př́ijem maximální:

$$
T R=(1-\delta) N \cdot(k+\varepsilon)=N\left(1-\gamma \frac{\varepsilon}{\varepsilon_{\max }}\right)(k+\varepsilon)
$$

Ve vztahu (7) opět předpokládáme splnění podmínky $(1-\delta) \cdot N<n$, v opačném prrípadě by totiž bylo možné zápisné ještě zvýšit, aby počet uchazečů poklesl na $n$ studentů. Pro počet přijatých studentů $n_{p}$ platí: $n_{p} \leq n$.

Situace A není př́liš zajímavá: daná vysoká škola sice ztratí část zájemců o studium, nicméně jí zůstane dostatečný počet uchazečů, aby nabrala plánovaných (a financovaných) $n$ studentů. Tento př́pad pravděpodobně nastane u prestižních vysokých škol, jakou jsou Karlova univerzita nebo Masarykova univerzita, a atraktivních oborů, jako jsou právo, medicína, psychologie, apod. U těchto škol respektive oborů existuje velký převis poptávky o studium, a ani zápisné na tom nic podstatného nezmění. Tyto vysoké školy tedy mohou nastavit zápisné na maximální výši, a tím maximalizují svůj př́ijem.

Situace B je mnohem zajímavější, nebot'v tomto případě klesá počet uchazečů pod plánovaný počet přijímaných studentů $n$. Každý přijatý uchazeč sice přináší vysoké škole větší příjem (o zápisné), ale počet uchazečů je menší než bez zápisného. $V$ tomto případě má tedy smysl ptát se, jak nastavit výši zápisného, aby byl př́ijem vysoké školy daný vztahem (7) maximální. Proto dále bude pozornost věnována právě tomuto př́ípadu ( $\mathrm{V}$ další kapitole si navíc ukážeme, že případ B v sobě skrývá ještě dvě varianty).

\section{Model}

Ke stanovení optimální výše zápisného pro situaci (scénář) B byl vytvořen model s následujícími (zjednodušujícími) předpoklady: 
- Uchazeči o studium na vysoké škole si podávají jen jednu přihlášku na vysokou školu (každý uchazeč zahrnutý v počtu $N$ má opravdu zájem studovat danou vysokou školu, na kterou se hlásí).

- Počet studentů se již během roku nemění (studenti např́iklad nepřestupují ze školy na školu).

- Citlivost uchazečů o studium na výši zápisného (počet uchazečů, které odradí od studia daná výše zápisného) lze vyjádřit pomocí spojité neklesající (lineární) funkce.

- Existuje maximální výše (strop) zápisného závazná pro všechny vysoké školy.

- Všichni uchazeči platí stejné zápisné bez ohledu na to, jaký obor studují, zda ročník opakují, studují prezenčně nebo kombinovaně, nebo zda jde o zahraniční studenty.

- K určení optimálního zápisného je př́ijem vysoké školy modelován pouze jako př́jem za nastupující studenty, předpokládá se tedy, že zápisné bude zavedeno pouze pro tyto studenty. Pokud by bylo zavedeno zápisné pro již studující studenty, pak by bylo nutno dále předpokládat, že počty již studujících se po zavedení zápisného nezmění (nesníží), čímž se tento př́jem stane konstantním a neovlivní výsledky modelu.

Proměnné (vstupní a výstupní) modelu jsou uvedeny v Tabulce 1. Kromě označení a stručného popisu proměnných je $\mathrm{v}$ Tabulce 1 uveden i jejich definiční obor, který vesměs vyplývá z prredpokladů modelů uvedených výše.

Tabulka 1: Proměnné modelu

\begin{tabular}{|c|c|}
\hline Vstupní proměnné modelu & Výstupní proměnné modelu \\
\hline $\begin{array}{l}N \ldots \text { počet uchazečů o studium na dané vysoké škole, } \\
N \geq n\end{array}$ & $\varepsilon_{0} \ldots$ optimální výše zápisného v Kč, \\
\hline $\begin{array}{l}\text { n... maximální počet uchazečů, které hodlá vysoká } \\
\text { škola přijmout (studenti „placeni““ státem), } \\
n>0 \text {, }\end{array}$ & $\begin{array}{l}n_{p} \ldots \text { počet príijatých studentů za } 1 \text { rok při zavedení } \\
\text { zápisného, } 0 \leq n_{p} \leq n\end{array}$ \\
\hline $\begin{array}{l}\text { k...částka, kterou dostává od státu vysoká škola za } 1 \\
\text { studenta za } 1 \text { rok v Kč (normativ), }\end{array}$ & $\begin{array}{l}\text { TR...celkový prŕijem vysoké školy za nově přijaté } \\
\text { studenty za } 1 \text { rok v Kč. }\end{array}$ \\
\hline $\begin{array}{l}\varepsilon \ldots \text { výše zápisného za jeden rok (za dva semestry) v } \\
\text { Kč, } \varepsilon \in\left\langle 0, \varepsilon_{\max }\right\rangle\end{array}$ & \\
\hline $\begin{array}{l}\gamma \ldots \text {..citlivost" uchazečů na maximální výši zápisného, } \\
\gamma \in\langle 0,1\rangle,\end{array}$ & \\
\hline $\begin{array}{l}\delta(\varepsilon) \ldots \text { funkce citlivosti uchazečů na výši zápisného, } \\
\delta \in\langle 0, \gamma\rangle . N \cdot \delta \text { je počet uchazečů o studium, } \\
\text { které zápisné odradí od studia (funkce popisuje } \\
\text { úbytek uchazečů), }\end{array}$ & \\
\hline $\begin{array}{l}\delta(\varepsilon) \ldots \text { funkce citlivosti uchazečů na výši zápisného, } \\
\delta \in\langle 0, \gamma\rangle . N \cdot \delta \text { je počet uchazečů o studium, } \\
\text { které zápisné odradí od studia (funkce popisuje } \\
\text { úbytek uchazečů), }\end{array}$ & \\
\hline $\begin{array}{l}\varepsilon_{\max \ldots} \ldots \text { maximální možná (zákonem nebo vyhláškou } \\
\text { stanovená) výše zápisného na } 1 \text { rok v Kč. }\end{array}$ & \\
\hline
\end{tabular}

Zdroj: vlastní zpracování 
Extrémy funkce (7) najdeme pomocí první derivace:

$$
\begin{aligned}
& \frac{d T R}{d \varepsilon}=N\left(1-\frac{k \gamma+2 \gamma \varepsilon}{\varepsilon_{\max }}\right) \\
& \frac{d T R}{d \varepsilon}=0 \Rightarrow 1=\frac{k \gamma+2 \gamma \varepsilon}{\varepsilon_{\max }}
\end{aligned}
$$

Odkud dostáváme stacionární bod $\varepsilon_{0}$ :

$$
\varepsilon_{0}=\frac{\varepsilon_{\max }-k \gamma}{2 \gamma}
$$

Pomocí druhé derivace snadno ověŕíme, že bod $\varepsilon_{0}$ ze vztahu (10) je maximem př́ijmu. Odpovídající maximální př́jem $T R_{\max }$ je pak dán následujícím vztahem, který obdržíme dosazením (10) do (7):

$$
T R_{\max }=N\left(1-\gamma \frac{\varepsilon_{0}}{\varepsilon_{\max }}\right)\left(k+\varepsilon_{0}\right)=N\left(1-\frac{\varepsilon_{\max }-k \gamma}{2 \varepsilon_{\max }}\right)\left(k+\frac{\varepsilon_{\max }-k \gamma}{2 \gamma}\right)
$$

Hodnota optimálního zápisného a počet přijatých studentů jsou omezeny následujícími podmínkami:

$$
\begin{gathered}
0 \leq \varepsilon_{0} \leq \varepsilon_{\max } \\
0 \leq(1-\delta) \cdot N=\left(1-\gamma \frac{\varepsilon}{\varepsilon_{\max }}\right) \cdot N \leq n
\end{gathered}
$$

Z hlediska matematické analýzy tedy hledáme maximum funkce (7) na kompaktní množině $M$ vymezené podmínkami (12a) a (12b).

$\mathrm{V}$ řeči prezentovaného modelu podmínka optimalizace celkového př́imu $T R$ znamená najít maximum výrazu (7) v závislosti na $\varepsilon$ za daných hodnot $\gamma, k, N$ a $\varepsilon_{\max }$, které reprezentují vstupní parametry modelu.

Ze vztahu (10) však může vyjít pro některé konfigurace parametrů hodnota $\varepsilon_{0}$ nebo hodnota $(1-\delta) \cdot N$ nesplňující vztahy (12). To znamená, že lokální extrém (maximum) funkce (7) leží mimo vymezenou oblast $M$, na níž maximum hledáme. Protože je funkce (7) spojitá, lze v takovém př́ípadě využít Weierstrassovu větu: spojitá funkce na kompaktní množině na ní nabývá svého maxima a minima, viz např. Chiang a Wainwright (2005) nebo Kaňka a Henzler (2003). Není-li tedy extrém funkce uvnitř množiny $M$, musí být na její hranici, a tedy maximum nastává pro jednu z krajních možností: $\varepsilon_{0}=0, \varepsilon=\varepsilon_{\max }$; respektive $(1-\delta) \cdot N=n,(1-\delta) \cdot N=0$. Poslední rovnost však nastat nemůže kvůli podmínce $\gamma<1$.

Podrobnějším rozborem (a ověřením, že se jedná opravdu o maximum) lze zjistit, že:

- Pokud vyjde ze vztahu (10) $\varepsilon_{0}<0$, pak maximum funkce (7) nastává pro $\varepsilon_{0}=0$.

- Pokud vyjde ze vztahu (10) $\varepsilon_{0}>\varepsilon_{\max }$, pak maximum funkce (7) nastává pro $\varepsilon_{0}=\varepsilon_{\max }$. 
- Pokud není splněna podmínka $(12 b)$, konkrétně je $(1-\delta) \cdot N>n$, pak optimální výše zápisného nastává pro takovou hodnotu $\varepsilon_{0}=\varepsilon_{N}$, že je splněno:

$$
\left(1-\gamma \frac{\varepsilon_{N}}{\varepsilon_{\max }}\right) \cdot N=n
$$

Citlivostní analýza prezentovaného modelu, tedy zjištění vlivu změn výstupní proměnné $\mathrm{v}$ závislosti na změně vstupních proměnných, se redukuje na zjištění vlivu změny proměnné $\varepsilon$ na změnu celkového př́ijmu $T R$, nebot' se předpokládá, že ostatní parametry modelu budou v praxi (pro danou vysokou školu a daný semestr) známy a zafixovány. Dále ze vztahu (7) vyplývá, že funkční závislost $T R$ na $\varepsilon$ je kvadratická (a konkávní), a první derivace $T R$ podle $\varepsilon$, viz vztah (8), pak poskytuje závislost změny $T R$ na změně $\varepsilon$. Užití první (parciální) derivace je jedním z častých př́stupů k citlivostní analýze v rámci metody OFAT (one factor at a time), viz např. Cacuci (2003).

Aby si čtenář mohl učinit konkrétní představu, jak se bude (respektive může) měnit celkový př́jem v závislosti na různých hodnotách vstupních parametrů, především pak pro různé hodnoty citlivosti na výši zápisného, je užití modelu předvedeno v následující kapitole.

\section{Ilustrační příklady}

V této kapitole je ilustrováno využití prezentovaného modelu na několika př́kladech. Cílem všech př́kladů je maximalizovat př́ijem vysoké školy stanovením optimální výše zápisného.

Př́́klad 1. Necht' jsou dány tyto vstupní hodnoty: $N=2000, n=1100, \varepsilon_{\max }=20000$ Kč, $k=28000$ Kč, $\gamma=0,4$. Najděte výši zápisného, která maximalizuje př́jem (7).

Řešeni:

Nejprve ověříme, že se jedná o situaci B, pro kterou byl model zkonstruován: Při zavedení maximálního ročního zápisného se počet uchazečů sníží o $40 \%(\gamma=0,4)$ na 1200 , což je však stále více než $n$, a tedy není splněna podmínka $\left(1-\delta_{\max }\right) \cdot N<n$. V tomto př́ípadě tedy vysoká škola nastaví maximální zápisné.

Př́íklad 2. Necht' jsou dány tyto vstupní hodnoty: $N=2000, n=1900, \varepsilon_{\max }=20000 \mathrm{Kč}$, $k=28000 \mathrm{Kč}, \gamma=0,5$. Najděte výši zápisného, která maximalizuje př́jem (7).

Řě̌ení:

Nejprve ověříme, že se jedná o situaci B, pro kterou byl model zkonstruován: Při zavedení maximálního ročního zápisného se počet uchazečů sníží o $50 \%(\gamma=0,5)$ na 1000 , což je méně než $n$. Roční př́ijem vysoké školy by činil bez zápisného 53,2 mil. Kč.

S maximálním zápisným (ale jen s 1000 přijatými studenty) by tento př́jem činil 48 mil. Kč. Vysoká škola tedy zavede nižší než maximální zápisné. Ze vztahu (10) vypočteme optimální výši zápisného:

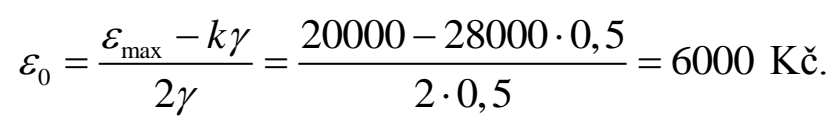


Pro zápisné ve výši $\varepsilon_{0}=6000$ Kč činí celkový prř́jem školy dle vztahu (11): 57,8 mil. Kč při počtu nastupujících studentů 1700. Nižší počet studentů je (více než) kompenzován vyšším př́ímem na jednoho studenta.

Zavedení optimální výše zápisného v tomto konkrétním příkladu přináší škole navíc 4,6 milionu Kč ročně oproti stavu bez zápisného, a téměř 10 milionů oproti stavu s maximálním zápisným. V Tabulce 2 jsou pro srovnání uvedeny př́ijmy vysoké školy pro různé výše zápisného $\mathrm{v}$ tomto př́kladu, a $\mathrm{v}$ Obrázku 1 je znázorněna závislost celkového př́jmu na parametru delta.

Příklad 3. Necht' jsou dány tyto vstupní hodnoty: $N=1400, n=1000, \varepsilon_{\max }=20000 \mathrm{Kč}$, $k=28000 \mathrm{Kč}, \gamma=0,5$. Najděte výši zápisného, která maximalizuje př́ijem (7).

Řešení:

Opět ověříme, že se jedná o situaci B: Při zavedení maximálního ročního zápisného se počet uchazečů sníží o $50 \%(\gamma=0,5)$ na 700 , což je méně než $n=1000$. Roční prŕíjem vysoké školy by činil bez zápisného 28 mil. Kč. S maximálním zápisným (ale jen se 700 přijatými studenty) by tento př́jem činil 33,6 mil. Kč. Ze vztahu (10) vypočteme optimální výši zápisného:

$$
\varepsilon_{0}=\frac{\varepsilon_{\max }-k \gamma}{2 \gamma}=\frac{20000-28000 \cdot 0,5}{2 \cdot 0,5}=6000 \mathrm{Kč} .
$$

Výše zápisného je stejná jako v Př́kladu 1. Avšak v tomto př́ípadě není splněna podmínka (12b):

$$
\left(1-\gamma \frac{\varepsilon}{\varepsilon_{\max }}\right) \cdot N=\left(1-0,5 \frac{6000}{24000}\right) \cdot 1400=1225>n=1000 .
$$

Muselo by být totiž přijato více studentů (1225), než je povoleno (1000). Vypočtený lokální extrém tedy neleží v oblasti $M$ vymezené podmínkami (12a,b). Optimální výše zápisného však přesto může být stanovena, a to z podmínky (13). Budeme tedy hledat maximum na hranici oblasti $M$ :

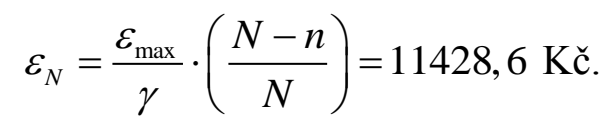

Př́i této výši zápisného $(N=1000)$ bude celkový př́iem VŠ ze vztahu (11): 39,43 mil. Kč. V Tabulce 3 jsou pro srovnání uvedeny př́ijmy vysoké školy pro různé výše zápisného $\mathrm{v}$ tomto príkladu.

Příklad 4. Necht' jsou dány tyto vstupní hodnoty: $N=1200, n=1000, \varepsilon_{\max }=10000$ Kč, $k=28000$ Kč, $\gamma=0,2$. Najděte výši zápisného, která maximalizuje př́ijem (7).

Řě̌ení:

Opět ověříme, že se jedná o situaci B: Při zavedení maximálního ročního zápisného se počet uchazečů sníží o 20 \% na 960, což je méně než $n=1000$. Nižší hodnota $\gamma$ než v Příkladech 1 a 2 vyjadřuje nižší citlivost uchazečů na výši zápisného, se zvyšováním zápisného tedy nedochází $\mathrm{k}$ takovému úbytku zájemců o studium jako v předchozích př́ípadech.

Roční př́ijem vysoké školy by činil bez zápisného 28 mil. Kč, a s maximálním zápisným 36,48 mil. Kč. Ze vztahu (10) vypočteme optimální výši zápisného: 


$$
\varepsilon_{0}=\frac{\varepsilon_{\max }-k \gamma}{2 \gamma}=\frac{10000-28000 \cdot 0,2}{2 \cdot 0,2}=11000 \mathrm{Kč} .
$$

Nyní ale není splněna podmínka (12a): výše zápisného je vyšší než maximální povolená výše zápisného. Ačkoli leží vypočtený extrém opět mimo hranice modelu, optimální výše zápisného přesto může být stanovena, a to na hranici oblasti $M: \varepsilon_{0}=\varepsilon_{\max }=10000 \mathrm{Kč}$. V Tabulce 4 jsou pro srovnání uvedeny př́jmy vysoké školy pro různé výše zápisného $\mathrm{v}$ tomto príḱladu.

Tabulka 2: Celkové př́ijmy v závislosti na výši zápisného a počtu přijatých studentů z Př. 2.

\begin{tabular}{|c|c|c|c|c|c|c|c|c|}
\hline $\boldsymbol{N}$ & $\boldsymbol{n}$ & $\boldsymbol{n}_{\boldsymbol{p}}$ & $\boldsymbol{k}$ & $\boldsymbol{\gamma}$ & $\boldsymbol{\delta}$ & $\boldsymbol{\varepsilon}$ & $\boldsymbol{\varepsilon}_{\max }$ & $\boldsymbol{T R}(\mathrm{K}$ č \\
\hline 2000 & 1900 & 1900 & 28000 & 0,5 & 0 & 0 & 20000 & 53200000 \\
\hline 2000 & 1900 & 1900 & 28000 & 0,5 & 0,05 & 2000 & 20000 & 57000000 \\
\hline 2000 & 1900 & 1850 & 28000 & 0,5 & 0,075 & 3000 & 20000 & 57350000 \\
\hline 2000 & 1900 & 1800 & 28000 & 0,5 & 0,1 & 4000 & 20000 & 57600000 \\
\hline 2000 & 1900 & 1750 & 28000 & 0,5 & 0,125 & 5000 & 20000 & 57750000 \\
\hline 2000 & 1900 & 1700 & 28000 & 0,5 & 0,15 & 6000 & 20000 & 57800000 \\
\hline 2000 & 1900 & 1650 & 28000 & 0,5 & 0,175 & 7000 & 20000 & 57750000 \\
\hline 2000 & 1900 & 1600 & 28000 & 0,5 & 0,2 & 8000 & 20000 & 57600000 \\
\hline 2000 & 1900 & 1550 & 28000 & 0,5 & 0,225 & 9000 & 20000 & 57350000 \\
\hline 2000 & 1900 & 1500 & 28000 & 0,5 & 0,25 & 10000 & 20000 & 57000000 \\
\hline 2000 & 1900 & 1450 & 28000 & 0,5 & 0,275 & 11000 & 20000 & 56550000 \\
\hline 2000 & 1900 & 1400 & 28000 & 0,5 & 0,3 & 12000 & 20000 & 56000000 \\
\hline 2000 & 1900 & 1350 & 28000 & 0,5 & 0,325 & 13000 & 20000 & 55350000 \\
\hline 2000 & 1900 & 1300 & 28000 & 0,5 & 0,35 & 14000 & 20000 & 54600000 \\
\hline 2000 & 1900 & 1250 & 28000 & 0,5 & 0,375 & 15000 & 20000 & 53750000 \\
\hline 2000 & 1900 & 1200 & 28000 & 0,5 & 0,4 & 16000 & 20000 & 52800000 \\
\hline 2000 & 1900 & 1150 & 28000 & 0,5 & 0,425 & 17000 & 20000 & 51750000 \\
\hline 2000 & 1900 & 1100 & 28000 & 0,5 & 0,45 & 18000 & 20000 & 50600000 \\
\hline 2000 & 1900 & 1050 & 28000 & 0,5 & 0,475 & 19000 & 20000 & 49350000 \\
\hline 2000 & 1900 & 1000 & 28000 & 0,5 & 0,5 & 20000 & 20000 & 48000000 \\
\hline
\end{tabular}

Zdroj: vlastní zpracování

Obrázek 1: Závislost celkových příjmů $T R$ (mil. Kč) v závislosti parametru $\delta$ z Př́ikladu 2.

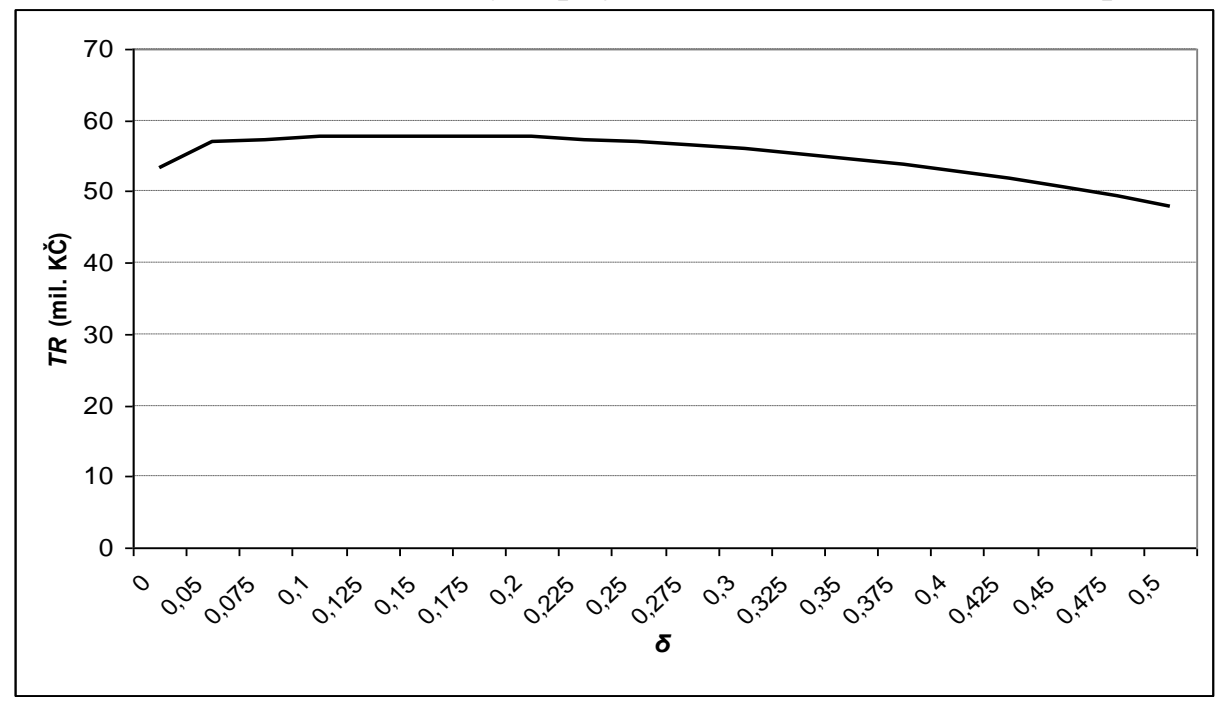

Zdroj: vlastní zpracování 
Tabulka 3: Celkové př́jmy v závislosti na výši zápisného a počtu přijatých studentů z Př. 3 .

\begin{tabular}{|c|c|c|c|c|c|c|c|c|}
\hline $\boldsymbol{N}$ & $\boldsymbol{n}$ & $\boldsymbol{n}_{\boldsymbol{p}}$ & $\boldsymbol{k}$ & $\boldsymbol{\gamma}$ & $\boldsymbol{\delta}$ & $\boldsymbol{\varepsilon}$ & $\boldsymbol{\varepsilon}_{\boldsymbol{m a x}}$ & $\boldsymbol{T} \boldsymbol{R}(\mathrm{Kc})$ \\
\hline 1400 & 1000 & 1000 & 28000 & 0,5 & 0 & 0 & 20000 & 28000000 \\
\hline 1400 & 1000 & 1000 & 28000 & 0,5 & 0,025 & 1000 & 20000 & 29000000 \\
\hline 1400 & 1000 & 1000 & 28000 & 0,5 & 0,05 & 2000 & 20000 & 30000000 \\
\hline 1400 & 1000 & 1000 & 28000 & 0,5 & 0,075 & 3000 & 20000 & 31000000 \\
\hline 1400 & 1000 & 1000 & 28000 & 0,5 & 0,1 & 4000 & 20000 & 32000000 \\
\hline 1400 & 1000 & 1000 & 28000 & 0,5 & 0,125 & 5000 & 20000 & 33000000 \\
\hline 1400 & 1000 & 1000 & 28000 & 0,5 & 0,15 & 6000 & 20000 & 34000000 \\
\hline 1400 & 1000 & 1000 & 28000 & 0,5 & 0,175 & 7000 & 20000 & 35000000 \\
\hline 1400 & 1000 & 1000 & 28000 & 0,5 & 0,2 & 8000 & 20000 & 36000000 \\
\hline 1400 & 1000 & 1000 & 28000 & 0,5 & 0,225 & 9000 & 20000 & 37000000 \\
\hline 1400 & 1000 & 1000 & 28000 & 0,5 & 0,25 & 10000 & 20000 & 38000000 \\
\hline 1400 & 1000 & 1000 & 28000 & 0,5 & 0,275 & 11000 & 20000 & 39000000 \\
\hline 1400 & 1000 & 980 & 28000 & 0,5 & 0,3 & 12000 & 20000 & 39200000 \\
\hline 1400 & 1000 & 945 & 28000 & 0,5 & 0,325 & 13000 & 20000 & 38745000 \\
\hline 1400 & 1000 & 910 & 28000 & 0,5 & 0,35 & 14000 & 20000 & 38220000 \\
\hline 1400 & 1000 & 875 & 28000 & 0,5 & 0,375 & 15000 & 20000 & 37625000 \\
\hline 1400 & 1000 & 840 & 28000 & 0,5 & 0,4 & 16000 & 20000 & 36960000 \\
\hline 1400 & 1000 & 805 & 28000 & 0,5 & 0,425 & 17000 & 20000 & 36225000 \\
\hline 1400 & 1000 & 770 & 28000 & 0,5 & 0,45 & 18000 & 20000 & 35420000 \\
\hline 1400 & 1000 & 735 & 28000 & 0,5 & 0,475 & 19000 & 20000 & 34545000 \\
\hline 1400 & 1000 & 700 & 28000 & 0,5 & 0,5 & 20000 & 20000 & 33600000 \\
\hline
\end{tabular}

Zdroj: vlastní zpracování

Tabulka 4: Celkové př́ijmy v závislosti na výši zápisného a počtu přijatých studentů z Př. 4.

\begin{tabular}{|c|c|c|c|c|c|c|c|c|}
\hline$N$ & $n$ & $n_{p}$ & $k$ & $\gamma$ & $\delta$ & $\varepsilon$ & $\varepsilon_{\max }$ & $T R(\mathrm{Kč})$ \\
\hline 1200 & 1000 & 1000 & 28000 & 0,2 & 0 & 0 & 10000 & 28000000 \\
\hline 1200 & 1000 & 1000 & 28000 & 0,2 & 0,02 & 1000 & 10000 & 29000000 \\
\hline 1200 & 1000 & 1000 & 28000 & 0,2 & 0,04 & 2000 & 10000 & 30000000 \\
\hline 1200 & 1000 & 1000 & 28000 & 0,2 & 0,06 & 3000 & 10000 & 31000000 \\
\hline 1200 & 1000 & 1000 & 28000 & 0,2 & 0,08 & 4000 & 10000 & 32000000 \\
\hline 1200 & 1000 & 1000 & 28000 & 0,2 & 0,1 & 5000 & 10000 & 33000000 \\
\hline 1200 & 1000 & 1000 & 28000 & 0,2 & 0,12 & 6000 & 10000 & 34000000 \\
\hline 1200 & 1000 & 1000 & 28000 & 0,2 & 0,14 & 7000 & 10000 & 35000000 \\
\hline 1200 & 1000 & 1000 & 28000 & 0,2 & 0,16 & 8000 & 10000 & 36000000 \\
\hline 1200 & 1000 & 984 & 28000 & 0,2 & 0,18 & 9000 & 10000 & 36408000 \\
\hline 1200 & 1000 & 960 & 28000 & 0,2 & 0,2 & 10000 & 10000 & 36480000 \\
\hline
\end{tabular}

Zdroj: vlastní zpracování

\section{Modely s obecnou závislostí mezi výši zápisného a počtem uchazečů}

V předchozích kapitolách jsme uvažovali lineární závislost mezi výší zápisného a úbytkem uchazečů o studium. Obecně je funkce $\delta$, která popisuje úbytek uchazečů v závislosti na výši zápisného, funkcí výše zápisného $\varepsilon$, je tedy $\delta(\varepsilon)$.

Funkce $\delta(\varepsilon)$ musí splňovat podmínky (3a,b), a navíc lze požadovat, aby byla funkce $\delta(\varepsilon)$ na celém svém definičním oboru neklesající (což odpovídá „rozumnému“ požadavku, aby se při rostoucím zápisném úbytek zájemců o studium nesnižoval).

Pak již můžeme přeformulovat vztah (7) pro situaci B na obecnější vztah (14): 


$$
T R=[1-\delta(\varepsilon)] N \cdot(k+\varepsilon),
$$

Extrémy funkce (14) opět hledáme užitím první derivace:

$$
\frac{d T R}{d \varepsilon}=N\left[1-k \delta^{\prime}(\varepsilon)-\varepsilon \delta(\varepsilon)-\delta(\varepsilon)\right]=0
$$

Ze vztahu (15) dostaneme (implicitní) podmínku pro stacionární bod $\varepsilon_{0}$ :

$$
k \delta^{\prime}\left(\varepsilon_{0}\right)-\varepsilon_{0} \delta\left(\varepsilon_{0}\right)-\delta\left(\varepsilon_{0}\right)=1
$$

Celkový př́ijem vysoké školy pak vypočteme ze vztahu (11), do kterého dosadíme $\varepsilon_{0}$ ze vztahu (16). Přitom stále požadujeme splnění podmínek (12a, b).

Snadno se můžeme přesvědčit, že pro $\delta(\varepsilon)=\gamma \frac{\varepsilon}{\varepsilon_{\max }}$ přejde podmínka (16) na podmínku (10). Jako př́íklad nelineární funkce citlivosti uchazečů na výši zápisného splňující podmínky $(3 a, b)$ může sloužit následující funkce:

$$
\delta(\varepsilon)=\gamma \frac{\left(e^{\varepsilon}-1\right)}{\left(e^{\varepsilon_{\max }}-1\right)}
$$

Ve funkci (17) se počet studentů odrazených zápisným exponenciálně zvětšuje s rostoucím zápisným, viz též Obrázek 2. Nelineární funkce, jako např́iklad zmíněná funkce (17), mohou umožnit přesnější modelování (za předpokladu, že reálná funkce citlivost $\delta(\varepsilon)$ je spíše nelineární než lineární, což ovšem musí být zjištěno empiricky), za cenu poněkud obtížnějších numerických výpočtů, nebot' rovnice (16) pak obvykle vede na nelineární rovnice, jejichž řešení je nutno hledat numerickými iteračními metodami, například metodou půlení, tečen, sečen nebo Newtonovou-Raphsonovou metodou.

Obrázek 2: Graf funkce citlivosti pro $\gamma=0,7$ a $\varepsilon_{\max }=20000: \delta_{1}(\varepsilon)=\gamma \frac{\varepsilon}{\varepsilon_{\max }}, \delta_{2}(\varepsilon)=\gamma \frac{\left(e^{\varepsilon}-1\right)}{\left(e^{\varepsilon_{\max }}-1\right)}$

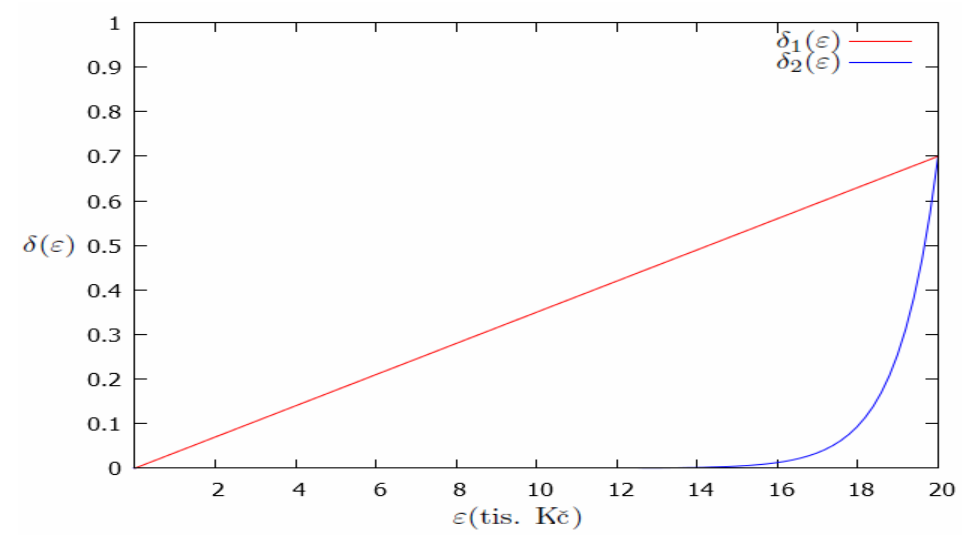

Zdroj: vlastní zpracování

\section{Zjištění koeficientu citlivosti v praxi}

Ke zjištění alespoň orientační hodnoty koeficientu $\gamma$ byla provedena anketa mezi studenty maturitního ročníku $(n=40)$ jednoho gymnázia v Moravskoslezském kraji. Maturantům byla položena jediná otázka: „Jaká výše zápisného (za rok) v Kč by vás odradila od studia na vysoké škole?““. Odpovědi respondenti̊ jsou znázorněny v Obrázku 3, z nich empiricky zjištěná funkce citlivosti je na Obrázku 4. Bylo zjištěno, že průměrná výše ročního zápisného, která by maturanty odradila, je 15800 Kč, medián byl 12000 Kč a modus 10000 Kč. Č́stka $6000 \mathrm{Kč}$ by neodradila žádného $\mathrm{z}$ respondentů. Koeficient $\gamma$ pro maximální roční zápisné 
20000 Kč činil 0,82. Tato vysoká hodnota naznačuje vysokou citlivost budoucích vysokoškolských studentů na výši zápisného, ačkoli k přesnějšímu stanovení koeficientu $\gamma$ by samozřejmě musela být provedena mnohem rozsáhlejší a především reprezentativnější studie zahrnující i bohatší regiony České republiky (Prahu, Brno, apod.), kde je možné očekávat výrazně nižší citlivost studentů na výši zápisného než v Moravskoslezském kraji.

Prezentované výsledky ankety je proto třeba chápat především jako ilustraci toho, jak by bylo možné zjistit citlivost studentů na výši zápisného v praxi. Dále je možné správně namítnout, že výdaje na studium nesou rodiče, a ne samotní maturanti - uchazeči o studium, na druhou stranu maturanti jistě mají alespoň přibližnou představu, co si jejich rodiny mohou dovolit.

Obrázek 3: Relativní četnosti odpovědí respondentů na otázku: „Jaká výše zápisného (za rok) v Kč by vás odradila od studia na vysoké škole?““

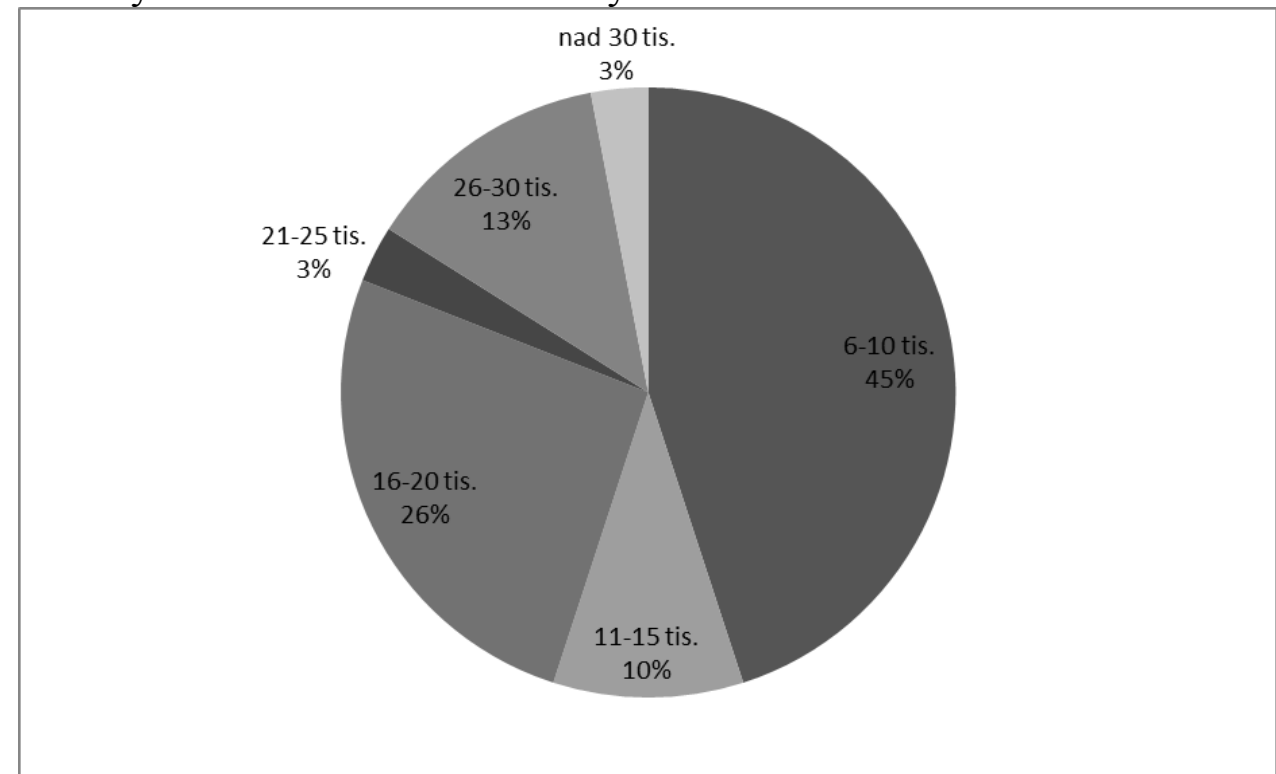

Zdroj: vlastní zpracování

Obrázek 4: Empiricky zjištěný průběh funkce citlivosti $\delta(\varepsilon)$

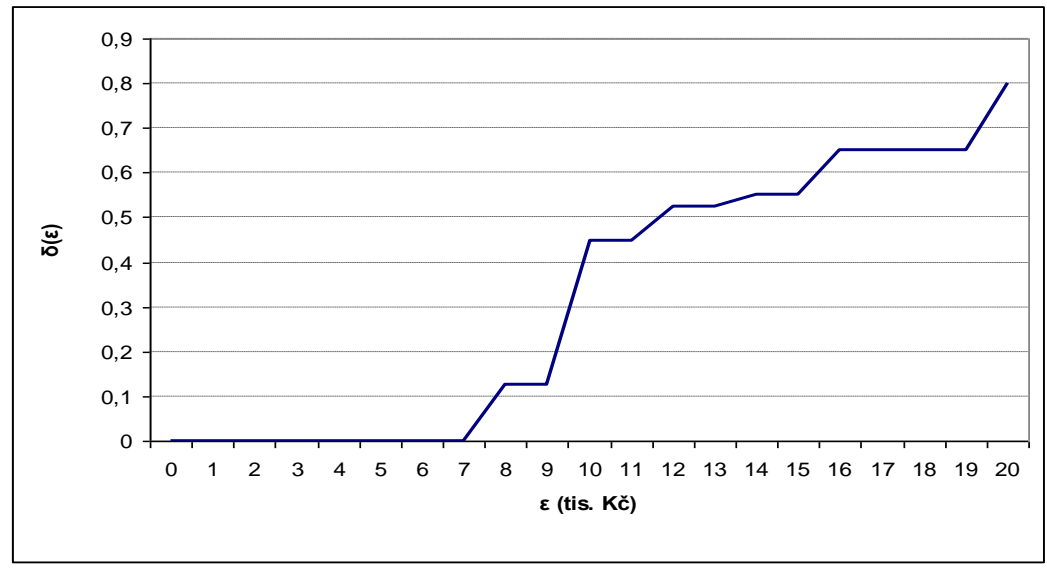

Zdroj: vlastní zpracování

\section{Omezení modelu, alternativní přístup k modelování výše zápisného}

Prezentovaný model je založen na několika předpokladech uvedených v Kapitole 2, které zároveň reprezentují omezení modelu. První dva jmenované předpoklady jsou do jisté míry nerealistické, otázkou však je, jak by bylo možné je realisticky zahrnout do prezentovaného modelu, nebot' zjištění počtu uchazečů rozhodnutých skutečně nastoupit na danou vysokou 
školu je obtížné, a zjištění počtu studentů, kteří v průběhu příštího akademického roku přestoupí z jiné školy nebo odejdou na jinou školu, je v podstatě nemožné. Některé z dalších předpokladů, jako je například předpoklad maximální výše zápisného, budou pravděpodobně realizovány v praxi. Předpoklad, že každý student dané vysoké školy bude platit stejné zápisné bez ohledu na obor nebo ročník, může být z modelu vypuštěn, pokud se v budoucnu ukáže, že tomu tak není. Až budou zatím nevyřešené otázky ohledně zápisného zodpovězeny, mohou být zahrnuty do modelu, který se tím stane přesnějším a v praxi užitečnějším. Realističtější model by mohl zahrnovat koeficient ekonomické náročnosti oborů (který je u různých oborů odlišný), vliv přijímacích zkoušek nebo konkurenci mezi vysokými školami.

Nejvýraznějším praktickým omezením prezentovaného modelu je tak určení koeficientu $\gamma$, který charakterizuje citlivost uchazečů na výši zápisného. Tento koeficient pro danou vysokou školu může být v principu určen dvěma způsoby:

- dotazníkovým šetřením mezi budoucími uchazeči o studium na dané vysoké škole (především mezi maturanty), jak bylo ukázáno v Kapitole 5,

- zjištěním skutečného poklesu uchazečů po zavedení zápisného (toto zjištění se pak využije ke stanovení nového zápisného pro př́ští rok).

Modelování prríjmu vysokých škol po zavedení zápisného by bylo možné i pomocí teorie her a multiagentních systémů, viz např. Cahlík et al. (2008). Jednotlivé veřejné vysoké školy (nebo jejich skupiny či fakulty) by stanovovaly výši zápisného ve vazbě na ostatní (konkurenční) vysoké školy tak, aby maximalizovaly své př́ijmy. Tento prŕístup by vyžadoval analýzu konkurence mezi vysokými školami. Otázkou je, do jaké míry si české veřejné vysoké školy skutečně konkurují, nebot' i přes demografický pokles a existenci více než 40 soukromých vysokých škol existuje na většině veřejných vysokých škol a oborů (s výjimkou oborů technických nebo př́rodovědných) převis poptávky nad nabídkou, který je velmi výrazný zvláště u našich historicky nejstarších univerzit. Strategie jednotlivých vysokých škol by zahrnovaly různé výše zápisného, problémem by však mohlo být sestavení realistické výplatní matice pro všechny uvažované subjekty, zvláště pokud vezmeme v úvahu, že situace na „trhu“ vysokých škol se může každoročně výrazně měnit.

\section{Závěr}

I přes jistá omezení modelu zmíněná v Kapitolách 2 a 6 může být prezentovaný model velmi užitečný pro řadu veřejných vysokých škol pro stanovení optimální výše zápisného tak, aby celkové př́ijmy za nastupující studenty byly maximální. Nesprávně nastavená výše zápisného může způsobit vysoké škole finanční ztráty ve výši jednotek až desítek milionů korun ročně. Se zavedením zápisného však vyvstává řada dosud nevyřešených otázek. Není např́íklad jasné, zda budou zápisné platit i studenti opakující ročník nebo zahraniční studenti, zda bude zápisné povinné pouze pro studenty, kteří teprve nastoupí na vysokou školu, nebo i pro ty, kteří již nyní studují, zda se zápisné bude lišit na jednotlivých fakultách jedné vysoké školy, př́padně na různých oborech, apod. Až budou známy odpovědi na tyto a další otázky, je možné prezentovaný model dále zpřesnit a zdokonalit. I proto lze prezentovaný model př́ijmu veřejných vysokých škol po zavedení zápisného chápat jako pokus o matematický popis možné budoucí ekonomické reality, která je sice bouřlivě diskutována v médiích a na půdě vysokých škol, avšak v odborném tisku jí byla věnována zatím jen malá pozornost.

\section{Literatura}

[1] BOSSHARDT, D. I., L. LICHTENSTEIN and M. P. ZAPOROWSKI, 2009. A Model Of College Tuition Maximization. Contemporary Issues In Education Research, 2(1), 53-70. ISSN 940-5847. 
[2] BOSSHARDT, D. I., L. LICHTENSTEIN, G. PALUMBO and M. P. ZAPOROWSKI, 2010. Optimization Techniques for College Financial Aid Managers. Journal of Student Financial Aid, 40(3), 39-57. ISSN 0884-9153.

[3] BRYAN, G. A. and T. W. WHIPPLE, 1995. Tuition Elasticity of the Demand for Higher Education among Current Students: A Pricing Model. The Journal of Higher Education, 66(5), 560-574. ISSN 0022-1546.

[4] CACUCI, D. G., 2003. Sensitivity and Uncertainty Analysis: Theory, Volume I. Chapman \& Hall. ISBN 9781584881155.

[5] CAHLÍK, T., J. HLAVÁČEK a J. MARKOVÁ, 2008. Školné či dotace?: (simulace s modely systému vysokých škol). Politická ekonomie, 56(1), 54-66. ISSN 0032-3233.

[6] CHIANG, A. C. and K. WAINWRIGHT, 2005. Fundamental Methods of Mathematical Economics, 4th edition. New York: McGraw-Hill. ISBN 978-0070109100.

[7] COREY, S. M., 2007. The Trends In and Relationships Between Tuition Price, Institutional Aid, Enrollment, and Tuition Revenue and Their Determination of the Net Revenue Generated by Colleges and Universities from 1988 to 2000 [online]. Dissertation. University of Arizona. Available from: arizona.openrepository.com/ arizona/handle/10150/195551

[8] CRAVEN, B. D. and S. M. N. ISLAM, 2005. Optimization in Economics and Finance: Some Advances in Non-Linear, Dynamic, Multi-Criteria and Stochastic Models. Springer US. ISBN 978-0-387-24279-8.

[9] HAVELKA, S., M. LAGOVÁ a V. KOŘENÁ̌̌, 1994. Matematické modely v ekonomii. Ústí n. Labem: Univerzita J. E. Purkyně. ISBN 8070440961.

[10] KAŇKA, M. a J. HENZLER, 2003. Matematika 2. Praha: Ekopress. ISBN 80-86119-769

[11] KUBIŠOVÁ, Z. a O. LÁNSKÝ, 2012. Sociální důsledky zavedení školného na veřejných vysokých školách v ČR [online]. Dostupné z: www.cssd.cz/data/files/socialnidusledky-zavedeni-skolneho_1.pdf, 1-33

[12] PLEVNÝ, M. a M. ŽIŽKA, 2010. Modelování a optimalizace v manažerském rozhodování. Plzeň: Vydavatelství Západočeské univerzity. ISBN 978-80-7043-933-3. 